\title{
Gold nanoparticle uptake is enhanced by estradiol in MCF-7 breast cancer cells
}

This article was published in the following Dove Press journal:

International Journal of Nanomedicine

\author{
Carlos Lara-Cruz' \\ Javier E Jiménez-Salazar ${ }^{2}$ \\ Marcela Arteaga ${ }^{2}$ \\ Michelle Arredondo' \\ Eva Ramón-Gallegos ${ }^{3}$ \\ Nikola Batina' \\ Pablo Damián-Matsumura ${ }^{2}$ \\ 'Nanotechnology and Molecular \\ Engineering Laboratory, Department of \\ Chemistry, Division of Basic Science and \\ Engineering (DCBI), Universidad \\ Autónoma Metropolitana (UAM), Mexico \\ City, Mexico; ${ }^{2}$ Department of Biology of \\ Reproduction, Division of Biological \\ Sciences and Health (DCBS), Universidad \\ Autónoma Metropolitana (UAM), Mexico \\ City, Mexico; ${ }^{3}$ Department of \\ Morphology, National School of \\ Biological Sciences, Instituto Politécnico \\ Nacional, Mexico City, Mexico
}

Correspondence:

Pablo Damián-Matsumura

Molecular Endocrinology Laboratory, Department of Biology of Reproduction, Universidad Autónoma Metropolitana (UAM), Mexico City 09310, Mexico Tel +5255650l 9230

Email pdmatsumura@yahoo.com

Nikola Batina

Nanotechnology and Molecular

Engineering Laboratory, Department of

Chemistry, Universidad Autónoma

Metropolitana (UAM), Mexico City

09310, Mexico

Email bani@xanum.uam.mx
Purpose: In the present study, we investigated the effects of $17 \beta$-estradiol $\left(\mathrm{E}_{2}\right)$ on membrane roughness and gold nanoparticle (AuNP) uptake in MCF-7 breast cancer cells.

Methods: Estrogen receptor (ER)-positive breast cancer cells (MCF-7) were exposed to bare $20 \mathrm{~nm}$ AuNPs in the presence and absence of $1 \times 10^{-9} \mathrm{M} \mathrm{E}_{2}$ for different time intervals for up to $24 \mathrm{hrs}$. The effects of AuNP incorporation and $\mathrm{E}_{2}$ incubation on the MCF-7 cell surface roughness were measured using atomic force microscopy (AFM). Endocytic vesicle formation was studied using confocal laser scanning microscopy (CLSM). Finally, the results were confirmed by hyperspectral optical microscopy.

Results: High-resolution AFM images of the surfaces of MCF-7 membranes (up to $250 \mathrm{~nm}^{2}$ ) were obtained. The incubation of cells for $12 \mathrm{hrs}$ with AuNP and $\mathrm{E}_{2}$ increased the cell membrane roughness by $95 \%$ and $30 \%$ compared with the groups treated with vehicle (ethanol) or AuNPs only, respectively. This effect was blocked by an ER antagonist (7 $\alpha, 17 \beta-[9-[(4,4,5,5,5$-Pentafluoropentyl)sulfinyl]nonyl]estra-1,3,5(10)-triene-3,17-diol

[ICI] 182,780). Higher amounts of AuNPs were localized inside MCF-7 cells around the nucleus, even after $6 \mathrm{hrs}$ of $\mathrm{E}_{2}$ incubation, compared with vehicle-treated cells. Endolysosome formation was induced by $\mathrm{E}_{2}$, which may be associated with an increase in AuNP-uptake.

Conclusions: $\mathrm{E}_{2}$ enhances AuNP incorporation in MCF-7 cells by modulating of plasma membrane roughness and inducing lysosomal endocytosis. These findings provide new insights into combined nanotherapies and hormone therapies for breast cancer.

Keywords: nanotherapy, hormone therapy, estrogen-induced vesicle formation, AuNP cellular uptake, membrane roughness, endocytosis

\section{Introduction}

Breast cancer is a major public health problem that causes a large and increasing number of deaths among Mexican women. ${ }^{1}$ Although there are many treatment options for breast cancer, such as surgery, radiation, chemotherapy, and biological therapy, including hormone therapy, these options are not completely effective because of their lack of high selectivity. Therefore, the use of nanotechnology for cancer therapies has received considerable attention in recent years. ${ }^{2,3}$ Cancer nanotechnology is an interdisciplinary area of research of science, engineering, and medicine that has resulted in the development of extensive applications against breast cancer at different levels, such as early diagnosis, prediction, prevention, and personalized therapy ${ }^{4-6}$ using different types of nanostructures, including gold nanoparticles (AuNPs). ${ }^{7-9}$ Nanotherapeutic strategies for the treatment of breast cancer, which increase the sensitivity and efficacy of tumor targeting, are gaining traction because 
of advances in understanding of their molecular characteristics. $^{10-12}$ Thus, breast cancer has become the type of cancer with the greatest presence of nanotechnological therapeutic agents in clinical settings. ${ }^{13-15}$

Two fundamental processes are involved in differentiating malignant and nonmalignant cells: passive targeting and active targeting. The first process takes advantage of the enhanced permeability and retention (EPR) effect observed in tumors ${ }^{16}$ to increase the concentration of AuNPs. Active targeting ${ }^{17}$ involves the selective molecular recognition of antigens that are expressed on the surfaces of cancer cells to localize AuNPs to malignant cells or the exploitation of the membrane properties associated with malignancy. The development of AuNPs that actively target specific cells depends on a better understanding of the many factors affecting the characteristics of bare AuNPs, the behavior of tumor cells and the responses of tumor cells to external stimuli. ${ }^{2,18}$

AuNPs, either bare ${ }^{19}$ or functionalized, ${ }^{7}$ have received a great deal of attention in nanotherapeutic cancer treatment due to their unique optical properties, ${ }^{20}$ chemical stability, easy synthesis and functionalization, all of which make 20-nm AuNPs attractive candidates for use as targeting ligands, imaging labels, and therapeutic drugs. Furthermore, other functionalities of AuNPs allow for targeted molecular imaging and localized surface plasmon resonance (LSPR), revolutionizing breast cancer diagnosis and treatment. $^{10,21,22}$ It is worth noting that the size of AuNPs is important, since large AuNPs have been reported to be immobilized on the cell membrane of two types of malignant cells, namely, non-small cell lung (CL1-0) and cervical (HeLa) cancer cells, ${ }^{23}$ while small AuNPs $(<15 \mathrm{~nm})$ can be cytotoxic. ${ }^{24}$

Several physicochemical characteristics of AuNPs have been reported to modify the interaction kinetics between cells and proteins, ${ }^{25}$ however, the effects of AuNPs attached to the cell surface remain unelucidated. Since the binding of AuNPs to cancer cell membranes can influence the behavior of cells and the efficacy of therapeutic agents, several research groups have investigated the delivery mechanisms and of AuNPs to enhance the delivery effectiveness. ${ }^{26-28}$ In addition to the size and charge of AuNPs, the surface roughness, molecular structure of cationic surfactants and cell medium proteins that interact with AuNPs have been shown to play significant roles in the biophysical interactions with cancer cells and the mechanisms by which AuNPs are internalized by endocytosis. $^{29,30}$ Tan and Onur (2018) showed that
AuNPs are more effective in restricting the proliferation and mobility of human cervical cancer cells (HeLa) compared with nontumorigenic cells (mouse fibroblasts, L929), suggesting that cancer cells are more vulnerable to AuNP treatment. ${ }^{25}$

Recently, AuNPs were shown to be able to modify the membrane roughness of cells, which is measured with ultra-high-resolution imaging by atomic force microscopy (AFM), by modifying their structure and enhancing AuNP uptake. ${ }^{31}$ We previously demonstrated that the incorporation of 20-nm bare AuNPs modifies the roughness values $\left(\mathrm{RMS}_{[\mathrm{Rq}]}\right)$ of the plasma membrane of MCF-7 cells when incubated for longer than $6 \mathrm{hrs}(12,18$ and $24 \mathrm{hrs})$. These modifications consisted of increasing the roughness of the membrane when AuNPs came into contact with the cell surface and subsequently became incorporated into cells. Similarly, the bare AuNPs used in that study emitted a fluorescent signal at $626 \mathrm{~nm}$ ), thus allowing the distribution of these nanoparticles in the cellular interior to be monitored using confocal laser scanning microscopy (CLSM). These results helped to determine the association between changes in the plasma membrane roughness of MCF-7 cells with the incorporation and intracellular distribution of AuNPs as well as the formation of membrane pores linked to endocytosis uptake mechanisms as analyzed by AFM. ${ }^{18}$

A hallmark of breast cancer is its hormone dependency, especially to estrogens, which can induce different changes in breast epithelial cells. Most breast cancer cases are invasive ductal carcinomas that are associated with the expression of the estrogen receptor (ER), which could be a good indicator of the success of hormone therapy. ${ }^{32,33}$ However, the overexpression of this receptor or excessive exposure to estrogens are major determinants of risk for breast cancer. ${ }^{34-36}$

In ER-positive breast cancer, the ER receptor is responsible for the proliferative and growth effects of $17 \beta$ estradiol $\left(E_{2}\right)$, the primary estrogenic hormone, through a combination of genomic and nongenomic actions that have been described at different cell levels, including the plasma membrane. ${ }^{37,38}$ The effects of estrogens on vesicle formation via the ER were previously observed in different systems $^{39,40,41,42}$ related to lysosomal function in human breast cancer and hepatocarcinoma cell lines, ${ }^{43-46}$ suggesting the involvement of a type of receptor-mediated endocytosis. The mechanism of action of this phenomenon is unclear. However, it was suggested that $E_{2}$, through the membrane ER (mER), can regulate the structure of 
caveolin and other proteins in the 50-100 nanometer flasklike invaginations of the plasma membrane called caveolae, ${ }^{47,48}$ which are tightly associated with lipid rafts and play important roles in the regulation of cancer. ${ }^{49,50}$

Estrogens have also been shown to have a role in the movement of membrane vesicles to the nucleus to facilitate the internalization of $\mathrm{mER}$, an event that only takes place in the presence of its ligand. ${ }^{51}$ This mechanism can be used by different types of cells to uptake and internalize $20-45 \mathrm{~nm}$ $\mathrm{AuNPs}^{52,53}$ by receptor-mediated endocytosis. In contrast, because $E_{2}$ interacts with the membrane surface, it has been shown to significantly modulate membrane fluidity in different cell models, as measured by fluorescence polarization using the fluorescent dye DPH (1,6-diphenyl-hexa-1,3,5-triene). ${ }^{54,55}$ However, the effects of incubating cells with $\mathrm{E}_{2}$ together with AuNPs have remained largely uninvestigated.

In the present study, we investigated the effects of $E_{2}$ incubation on membrane roughness and AuNP uptake in MCF-7 breast cancer cells. Experiments were performed in the absence or presence of an ER antagonist, the results of which demonstrated that AuNP uptake is enhanced by an estrogen-dependent mechanism, suggesting that the uptake of AuNPs by cells occurs by both a passive phenomenon, due to the increase of the membrane roughness, and an endocytic pathway. In addition, we studied the estrogen-induced vesicle formation associated with AuNP uptake. Finally, we confirmed the intracellular AuNP distribution through hyperspectral optical microscopy.

\section{Materials and methods}

\section{Reagents}

The human breast cancer cell line MCF-7, which is positive for the ERs $\alpha$ and $\beta$, was obtained from the American Type Culture Collection (ATCC; Manassas, VA). Spherical AuNPs, $20 \mathrm{~nm}$ in diameter (SKU EM.GC20), were acquired from BBI Solutions (Cardiff, UK) for use in research and were verified by TEM. Dulbecco's Modified Eagle's Medium (DMEM) was purchased from Thermo Fisher Scientific Inc. (Waltham, MA). Dimethyl sulfoxide was purchased from Merck Millipore (Darmstadt, Germany). An antifungal antibiotic and fetal bovine serum (FBS) were purchased from Thermo Fisher Scientific. 17ß-Estradiol was acquired from Sigma-Aldrich Co. (Saint-Louis, MO). LysoTracker ${ }^{\circledR}$ (LT), a deep fluorescent dye for labeling and tracking acidic organelles, was obtained from Molecular Probes (Life Technologies Corporation, CA). All reagents we used in this study were of the highest research grade purity available.

\section{Cell culture}

MCF-7 cells were maintained and propagated in DMEM supplemented with $10 \%$ FBS and $1 \%$ penicillin/streptomycin. Cells were cultured as adherent monolayers (cultured to approximately $70 \%$ confluence) and maintained at $37{ }^{\circ} \mathrm{C}$ in a humidified atmosphere containing $5 \% \mathrm{CO}_{2}$. The cells were synchronized to the G0 stage of the cell cycle through serum deprivation techniques in DMEM supplemented with 2.5\% charcoal/dextran-treated FBS (FBS-C) and without phenol red. After brief trypsinization, the cells were harvested, counted and transferred to 24-well plates. Subsequently, the cells were incubated for $24 \mathrm{hrs}$ prior to the addition of AuNPs (20-nm; $80 \mu \mathrm{g} / \mathrm{mL}$ in DMEM) in the presence of vehicle $(0.1 \%$ ethanol), $\mathrm{E}_{2}\left(1 \times 10^{-9} \mathrm{M}\right)$ or the ER antagonist $7 \alpha, 17 \beta-[9$ [(4,4,5,5,5-Pentafluoropentyl)sulfinyl]nonyl]estra-1,3,5(10)triene-3,17-diol (ICI) $182,780\left(\mathrm{ICI} ; 1 \times 10^{-7} \mathrm{M}\right.$ ) for $6,12,18$ or $24 \mathrm{hrs}$, corresponding to $\mathrm{G} 0 / \mathrm{G} 1, \mathrm{~S}, \mathrm{G} 2$ and mitosis stages, respectively. AFM studies were performed in $1 \mathrm{~cm}^{2}$ gold plates using the same conditions. In most assays, three independent experiments were carried out, and all measurements were performed in triplicate. The cells were grown on a singlecrystal film with an $\mathrm{Au}(111)$ surface.

\section{Plasma membrane surface roughness analysis by AFM}

An AFM NanoScope III ${ }^{\circledR}$ (Veeco Inc., Plainview, NY) was used in a tapping mode to obtain topographic images using standard silicon probes (TESPA, Bruker Nano Inc., Camarillo, CA). The spring constant of the AFM probe was $20-80 \mathrm{~N} / \mathrm{m}$; the resonant frequency was between 382 and $405 \mathrm{kHz}$; and the nominal tip radius was $8 \mathrm{~nm}$ for all AFM measurements. MCF-7 cells were grown on a single-crystal film with an $\mathrm{Au}$ (111) surface as a substrate. The use of these plates provided excellent cell adherence uniformity, thus preventing defects or variation in cell morphology that can alter AFM analyses.

MCF-7 cells were incubated in a medium containing a mixture of $80 \mu \mathrm{g} / \mathrm{mL}$ AuNPs, $1 \times 10^{-9} \mathrm{M} \mathrm{E}_{2}$ and/or $1 \times 10^{-7} \mathrm{M}$ ICI at different times $(6,12,18$ and $24 \mathrm{hrs})$ to assess the plasma membrane roughness at each time point. At the end of each treatment, the cells were fixed by sequential dehydration with different concentrations of ethanol $(20,30,40,50,60$, $70,80,90$ and $100 \%$ ) for $2 \mathrm{~min}$ at each concentration, with the samples subsequently analyzed by AFM in the tapping mode. The analysis was performed on single cells to obtain $100 \times 100 \mu \mathrm{m}\left(100 \mu \mathrm{m}^{2}\right)$ images by moving the cantilever to the cell surface; images of 50, 20, 10, 5, 2.5, 1, 0.5 and $0.25 \mu \mathrm{m}^{2}$ were obtained sequentially in three different areas 
of the cell and on three different cells, in triplicate, and the mode height, phase and amplitude were recorded. ${ }^{18}$

\section{Evaluation of the cellular uptake of AuNPs}

Cells were cultured in chambered 8-well culture slides (LabTek II Chamber Slides; Thermo Fisher Scientific Inc.) for $24 \mathrm{hrs}$ and were subsequently incubated with a mixture of $80 \mu \mathrm{g} / \mathrm{mL}$ AuNPs, $1 \times 10^{-9} \mathrm{M} \mathrm{E}_{2}$ and/or $1 \times 10^{-7} \mathrm{M}$ ICI for $12 \mathrm{hrs}$. Similar results were observed when cells were pretreated with $\mathrm{E}_{2}$ and/or ICI. Control cells were incubated with ultrapure water (when compared with AuNPs alone) or ethanol (when compared with $E_{2}$, ICI or both). The cells were washed with a phosphate-buffered saline (PBS) solution and were fixed with $4 \%$ paraformaldehyde. For cell permeabilization, $0.01 \%$ Triton $\mathrm{X}-100$ was added to each tube and the cells were incubated for $30 \mathrm{~min}$ at $25^{\circ} \mathrm{C}$. Subsequently, the nuclei were stained with 4',6-diamidino-2-phenylindole (DAPI, Sigma-Aldrich Co.), and the cells were mounted with fluorescence mounting medium (Dako Cytomation, Glostrup, Denmark). Images were obtained using a Carl Zeiss LSM 780 NLO multiphoton confocal laser scanning microscope (Carl Zeiss Microscopy, Thornwood, NY). AuNPs were visualized without the use of fluorogenic probes to observe their distribution into the cell.

\section{Er-mediated cellular internalization of}

\section{aunps}

For LysoTracker staining, cells were cultured in chambered 8-well culture slides and treated with a mixture of $80 \mu \mathrm{g} / \mathrm{mL}$ AuNP, $1 \times 10^{-9} \mathrm{M} \mathrm{E}_{2}$ and/or $1 \times 10^{-7} \mathrm{M}$ ICI for $12 \mathrm{hrs}$. After treatment, the cells were incubated in PBS supplemented with $75 \mathrm{nM} \mathrm{LT}$. The cells were then washed with PBS and fixed with $4 \%$ paraformaldehyde in PBS for $15 \mathrm{~min}$ at room temperature, after which the nuclei were stained with DAPI. Subsequently, the slides were mounted with fluorescence mounting medium (Dako) and analyzed by CLSM.

\section{Single-cell analysis using hyperspectral imaging (HSI)}

A CytoViva ${ }^{\circledR}$ darkfield-based microscope system ${ }^{\circledR}$ (CytoViva, Inc., Auburn, AL) was used for hyperspectral data imaging acquisition. The microscope system is composed of a BC53 Olympus ${ }^{\circledR}$ microscope (Olympus America Inc., Center Valley, PA), a diffraction grating spectrophotometer $(400-1,000 \mathrm{~nm})$ integrated with a CCD (charge-coupled device), and a Fiber-Lite ${ }^{\circledR}$
DC950 Illuminator quartz halogen light source (DolanJenner Industries, Boxborough, MA). The image analysis was performed using ENVI 4.8 software with a spectral resolution of $2 \mathrm{~nm}$. Image dimensions of $696 \times 696$ pixels were obtained, with each pixel having a spatial area of 25 $\mathrm{nm}^{2}$ using an exposure time of 0.25 seconds to capture the complete visible near-infrared spectrum. ${ }^{56}$ Dark field microscopy coupled to a high resolution hyperspectral imaging (HSI) was performed to extend the optical resolution limit to $\lambda / 5 .{ }^{57}$ All of the components were correlated to obtain the highest possible resolution of scattering intensity. The samples were illuminated using a hollow cone of parallel rays, and the reflected light entered the coverslip along the optical axis. ${ }^{58}$ Hyperspectral images and spectra were produced as a data cube conforming to spatial information (X-Y) and spectral information (Z). The spectral library of endmembers involved multiple steps, such as selecting the region of interest (ROI), scanning the sample pixel-by-pixel and choosing the characteristic spectra. These data were collected and saved using the ENVI software and served as a guide to evaluate the AuNP accumulation and distribution within the cells. The same samples prepared for AFM characterization were used for HSI and were mounted on the motorized steeper Prior stage (H101A ProScan ${ }^{\circledR}$ stage, Prior Scientific Inc. Rockland, MA) with a minimum tap size of $40 \mathrm{~nm}$ in air at room temperature without sample manipulation. The resulting scattered light was collected with a 50X objective in reflectance mode. ${ }^{56}$

\section{Statistical analysis}

The data are presented as the means and standard deviation (SD) for at least three independent experiments carried out in triplicate. GraphPad Prism 8 (GraphPad Software, San Diego, CA) was used for analysis of variance (ANOVA). Comparisons between groups were performed using Tukey-Kramer multiple comparison tests. Differences were considered significant at $P<0.05$.

\section{Results and discussion}

\section{High-resolution AFM of MCF-7 cell surface roughness}

To compare the effects of AuNP and/or $E_{2}$ on cell membrane roughness, it was important to set the lower limit of achievable resolution, as expressed by $\mathrm{RMS}_{[\mathrm{Rq}]}$ values, at 8 different scan sizes $\left(50,20,10,5,1,0.6,0.5\right.$ and $\left.0.25 \mu \mathrm{m}^{2}\right)$ with decreasing height $(Z)$ measurements. We preliminarily analyzed untreated 
MCF-7 cells by repeating AFM imaging in the same region for a total of 512 data points, with this process repeated in three different regions of at least three cells. In Figure 1A, an image of a single MCF-7 cell was analyzed in a scan size of $50 \mu \mathrm{m}^{2}$ in phase imaging mode. Scans were performed systematically in different zones (Figure 1A to G; red arrowheads) at nanometric resolutions of up to 500 and $250 \mathrm{~nm}^{2}$ in height (3-D imaging mode) (Figure $1 \mathrm{H}$ to I). The obtained $\mathrm{RMS}_{[\mathrm{Rq}]}$ values for all scan sizes showed similar behaviors, and a representative image for each size is reported.

We used the human breast tumor cell line MCF-7 in our study because it is widely used to study breast cancer ${ }^{59}$ and the ER is highly expressed these cells. Plasma membrane roughness has been used as a sensitive indicator of the health state of cells in AFM-based studies. ${ }^{60}$

The membrane roughness of healthy ${ }^{61}$ and tumor cell surfaces has been previously analyzed under different drug treatments. ${ }^{62,63}$ However, the roughness values obtained depend on measurement parameters, such as the scanning area and step size, and can offer poor reproducibility. To the best of our knowledge, no studies have measured cell membrane roughness in a systematic way that would allow for the characterization of different-sized features of MCF-7 cell surface topology. We analyzed different cell zones to identify homogeneous characteristics and avoid false-positive results or possible
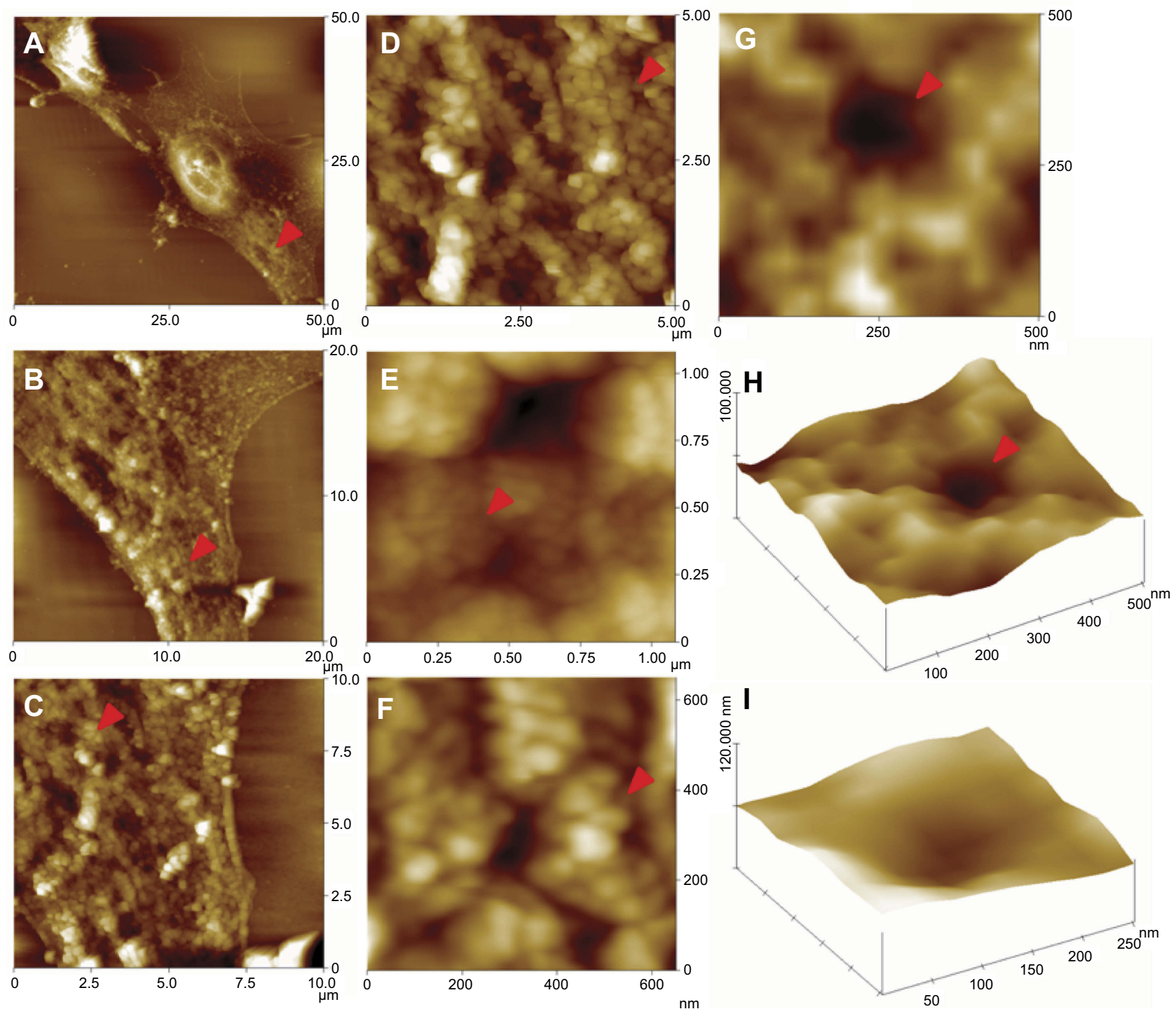

Figure I High resolution atomic force microscopy images revealed details of the MCF-7 membrane surface. Images: Show the surface (top-view presentation) which correspond to (A) $50 \times 50 \mu \mathrm{m},(\mathbf{B}) 20 \times 20 \mu \mathrm{m}$, (C) $10 \times 10 \mu \mathrm{m}$, (D) $5 \times 5 \mu \mathrm{m},(\mathbf{E})|\times| \mu \mathrm{m},(\mathbf{F}) 0.6 \times 0.6 \mu \mathrm{m},(\mathbf{G}) 0.5 \times 0.5 \mu \mathrm{m}$. Three-dimensional images for (H) $0.5 \times 0.5 \mu \mathrm{m}$ and (I) $0.25 \times 0.25 \mu \mathrm{m}$ were achieved. Red arrowheads show the zone where the next scan magnification was taking place. $Z$ values: $(\mathbf{A})=0-1532.57 \mathrm{~nm}$; $(\mathbf{B})=0-6 \mathrm{I} 6.2 \mathrm{~nm}$; $(\mathbf{C})$ $=0-519.13 \mathrm{~nm} ;(\mathbf{D})=0-366.5 \mathrm{~nm} ;(\mathbf{E})=0-78 \mathrm{~nm} ;(\mathbf{F})=0-50 \mathrm{~nm}$ and $(\mathbf{G})=0-30 \mathrm{~nm}$. 
AFM image artifacts related to feature height or image acquisition. $^{64}$

We previously observed that MCF-7 cell surface roughness is more homogeneous in cytoplasmic regions, between the cell edge and the nucleus zone, where cell roughness is higher and heterogeneous. ${ }^{18}$ This observation was consistent with other reports, where cell surface roughness values were observed to be significantly higher over nuclear areas than over cytoplasmic regions in three different epithelial cell lines. ${ }^{65}$

\section{Effects of estradiol and AuNP incubation on cell surface roughness}

The effects of 20-nm AuNPs on plasma membrane roughness in the presence or absence of $E_{2}$ were assessed under the same experimental conditions at a scan size of $5 \times 5 \mu \mathrm{m}$, as previously described. ${ }^{18}$ Human breast cancer MCF-7 cells were synchronized in the G0/G1-phase via serum deprivation for $48 \mathrm{hrs}$, ${ }^{66}$ after which the cells were exposed to $80 \mu \mathrm{g} / \mathrm{mL}$ of AuNP or $1 \times 10^{-9} \mathrm{M}$ of $\mathrm{E}_{2}$ for $6,12,18$ or $24 \mathrm{hrs}$. The $\mathrm{RMS}_{[\mathrm{Rq}]}$ values were calculated for each image according to previous studies, ${ }^{18}$ and the results of which are shown in Figure 2. The results demonstrate that the maximal response was obtained when cells were incubated simultaneously with AuNP and $\mathrm{E}_{2}$ for $12 \mathrm{hrs}$, with a $95 \%$ and $30 \%$ increase in the $\mathrm{RMS}_{[\mathrm{Rq}]}$ value compared to the groups treated with vehicle (ethanol) or AuNPs only, respectively. It has been established that the plasma membrane interaction, cellular uptake of
AuNPs and in vitro cytotoxicity are dependent on the physicochemical characteristics of AuNPs including size, shape, chemical composition; as well as the nature of the biological system, such as cell types, culture conditions, and exposure times. ${ }^{67}$ We have previously reported that the exposure of $20-\mathrm{nm}$ diameter spherical AuNPs $(80 \mu \mathrm{g} / \mathrm{mL})$ to MCF-7 breast cancer cells has no lethal effects, according to the results obtained in viability analyses. In a previous research we established the correct parameters for monitoring the interaction and incorporation of AuNPs in MCF-7 cells. ${ }^{18}$

To the best of our knowledge, this is the first report describing the effects of 20-nm AuNPs in combination with $\mathrm{E}_{2}\left(1 \times 10^{-9} \mathrm{M}\right)$ on the cell surface roughness of any cell line. Perner et al (2002) demonstrated that the surfaces of ERpositive human breast cancer cells (T-47D) became increasingly jagged at physiological $\mathrm{E}_{2}$ concentrations $\left(5 \times 10^{-9}\right.$ and $5 \times 10^{-7} \mathrm{M}$ ), as detected by an increase in membrane height in near-field light transmission images. ${ }^{68} \mathrm{MCF}-7$ cells have been reported to exhibit a more disorganized filamentous cytoskeleton structure, increased membrane roughness, decreased viscoelastic properties (elasticity and viscosity) and softer and more fluid membranes compared to benign breast cells MCF-10A. ${ }^{60}$ An increase in membrane roughness can also result from changes in the expression of cell surface proteins that may induce smoothening of the cell surface, including Cav-1 or clathrins, since the ER can induce changes in those proteins and in vesicle formation. ${ }^{47,69}$ On the other hand, it has been shown that progesterone, a steroid

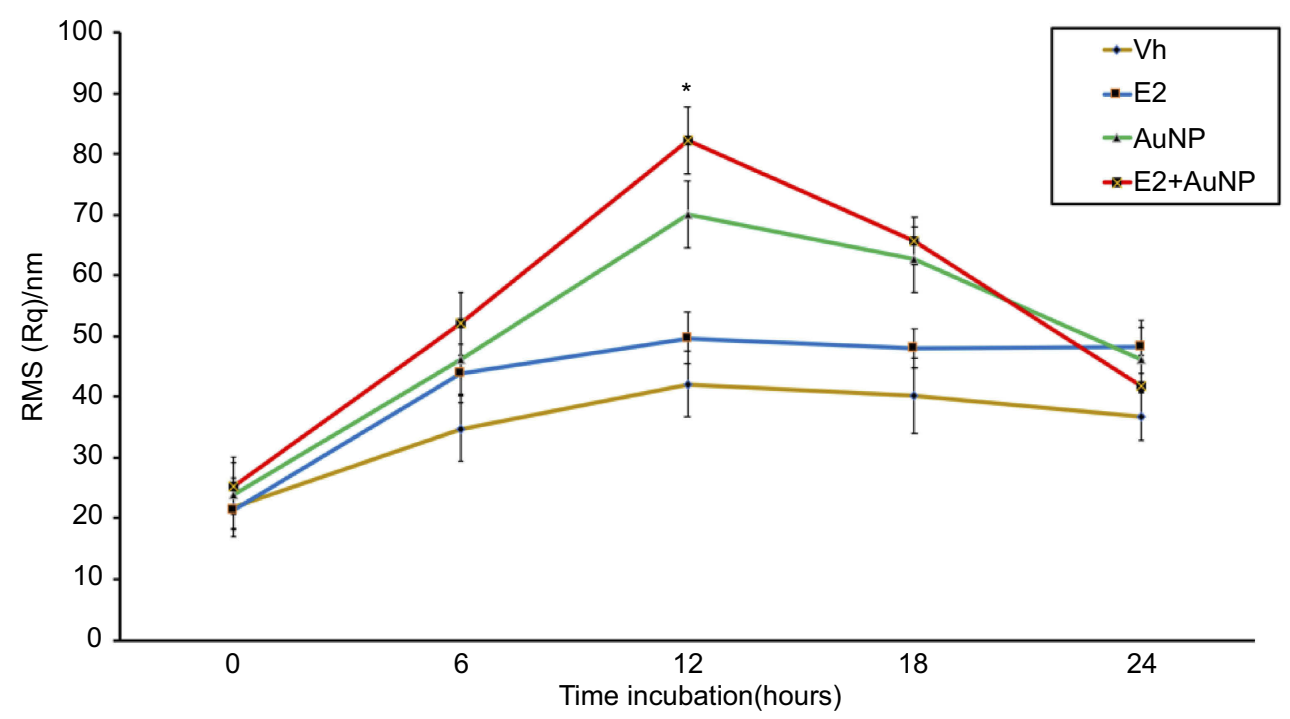

Figure 2 Surface roughness of the MCF-7 cells at different times of AuNP exposure, in the absence or presence of $E_{2}$. The RMS[Rq] values were evaluated after 6, 12 , 18 and $24 \mathrm{~h}$. Significative difference was observed at $12 \mathrm{hrs}$ of incubation with $\mathrm{E}_{2}+\mathrm{AuNP}$ treatment and the rest of times (6, 18 and 24 hrs) $P \leq 0.05$ vs 6,18 and $24 \mathrm{~h}$. Abbreviations: AuNP, gold nanoparticle; $E_{2}$, I7 $\beta$-estradiol; RMS[Rq], roughness values; Vh, vehicle. 


\section{A}

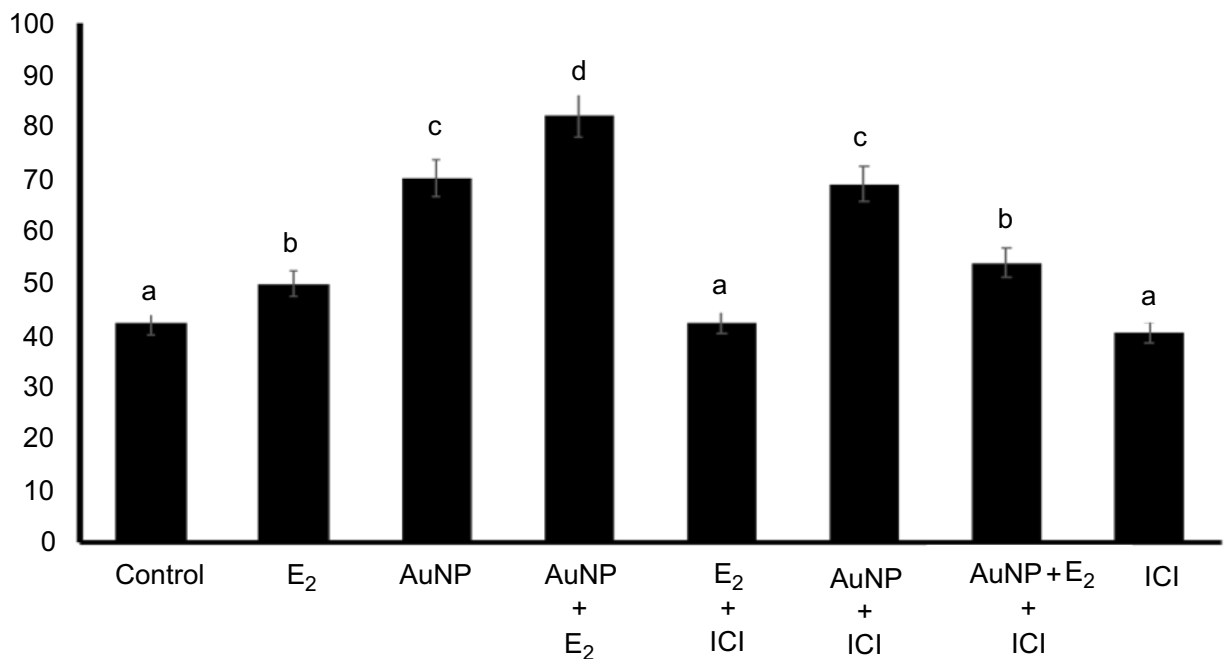

B

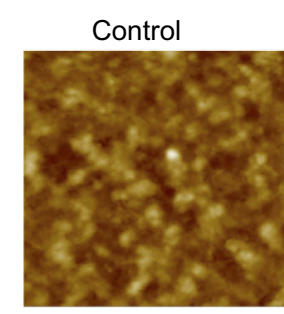

$E_{2}$

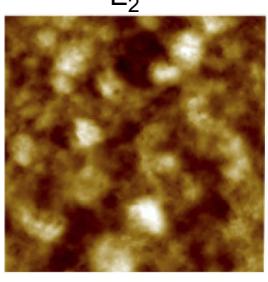

AuNP

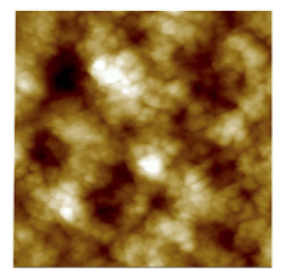

$A u N P+E_{2}$

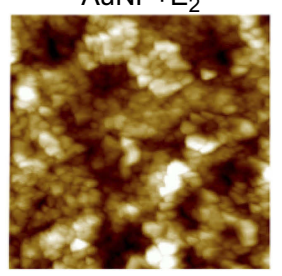

$\mathrm{E}_{2}+\mathrm{ICl}$

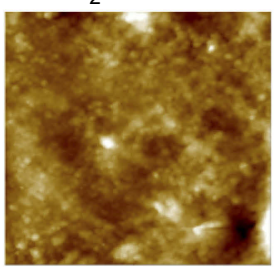

AuNP+ICl

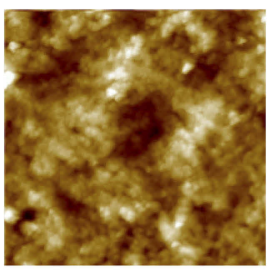

$\mathrm{AuNP}+\mathrm{E}_{2}+\mathrm{ICl}$

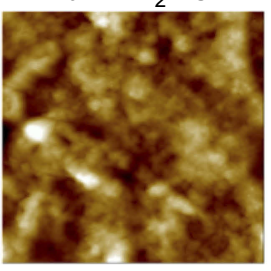

ICI

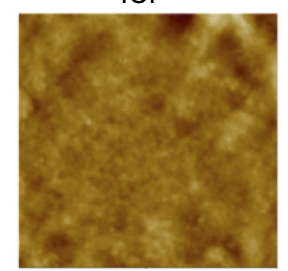

Figure 3 Effects of the ER-antagonist (ICl) on the $E_{2}$-induced increase of the MCF-7 cell membrane roughness, in the absence and presence of AuNP. (A) Graphic shows significant differences in the roughness values at $12 \mathrm{hrs}$ of incubation with different treatments compared with the control group (ethanol-treated cells). Results were obtained sequentially in three different areas of the cell and on three different cells, in triplicate. Different letters (a-d) show statistical differences between groups in the $\mathrm{RMS}[\mathrm{Rq}]$ value; $* P \leq 0.05$ vs control. (B) Representative high-resolution AFM images show changes in the surface roughness of the MCF-7 cell membrane under different treatments. The image size: $5 \times 5 \mu \mathrm{m}$, with $\mathrm{Z}=0$ a $250 \mathrm{~nm}$. $(0.25 \mu \mathrm{m})$.

Abbreviations: AFM, atomic force microscopy; AuNP, gold nanoparticle; $E_{2}$, I7 $\beta$-estradiol; ICl, 7 $\alpha, \mid 7 \beta-[9-[(4,4,5,5,5$-Pentafluoropentyl)sulfinyl]nonyl]estra-I,3,5(I0)-triene3, I7-diol; RMS[Rq], roughness values; Vh, vehicle.

hormone like $\mathrm{E}_{2}$, induces nanoscale molecular modifications, as measured by AFM, to the endometrial epithelial cells surface. Changes in average cell height and surface convolution correlated with increased surface roughness measurements in response to hormonal stimulation. The authors attribute these phenomena to a change in region-specific distribution of the cell surface protein MUC- $1 .^{70}$

To explain the behavior of the cell membrane roughness, several studies have examined the effects of various agents that modify membrane components. Wang et al (2009) reported that incubating cancer cell lines with anti-cancer drugs increased cell membrane roughness, as measured by AFM, concluding that the degree of damage to the cancer cell membranes had a positive correlation with exposure time (up to $1 \mathrm{hr}$ ), suggesting that these changes could be due to structural fluctuations on the surface components of the cell membrane. ${ }^{62}$ In similar experiments, Lee et al (2016) demonstrated that positively charged AuNPs increased neuroblastoma cell membrane roughness within $1 \mathrm{hr}$, which returned to the original level after 2 hrs, whereas negatively charged AuNPs did not cause significant changes in the membrane roughness. ${ }^{31}$ Notably, in the present study we evaluated the effects of AuNPs, $E_{2}$ or a combination of both for $24 \mathrm{hrs}$, observing that the effect of $E_{2}$ is reversible since cell membrane roughness declines after $18 \mathrm{hrs}$ of incubation, as previously reported for the incubation with AuNPs. ${ }^{18}$ This 
observation is in agreement with results from previous studies in which endocytic vesicle formation was shown to contribute to the degradation of mER, thus diminishing its effect. ${ }^{71}$

To show that the increase in $\mathrm{E}_{2}$-induced roughness was specific due to its interaction with its receptor, cells were incubated with the ER antagonist ICI in the presence or absence of $E_{2}$ or AuNP. $\mathrm{RMS}_{[\mathrm{Rq}]}$ values were measured after 12 hrs of incubation with AuNP or $E_{2}$. As shown in Figure $3 \mathrm{~A}$, the results of the receptor blockade study show that the ER antagonist fully diminished the effect of AuNPs $+E_{2}$ on membrane roughness, and no effect was observed when cells were incubated with ICI or AuNP + ICI. These results suggest that the cooperative effect of $E_{2}$ on increasing MCF-7-membrane roughness, induced by AuNPs, is due to a mechanism related to $\mathrm{E}_{2}$.

The AFM images presented in Figure 3B show that the ethanol-treated cell membrane was smooth and had no granular elevations (upper left panel), whereas cells incubated with AuNP $+E_{2}$ caused the formation of numerous pits (darker zones) throughout the cell membrane that increased its porosity (lower middle panel), suggesting the additive effect of these two agents. As expected, the ER antagonist (ICI) precluded the effect of $E_{2}$ in the presence of AuNP.

\section{Effect of E2 on the intracellular incorporation of aunps}

To demonstrate the effect of $E_{2}$ on the incorporation of AuNP into MCF-7 cells, cells were incubated for $12 \mathrm{hrs}$ (when the maximal effect was observed) with $80 \mu \mathrm{g} / \mathrm{mL}$ of an AuNP suspension mixed with DMEM containing 2.5\% FBS in the presence or absence of $1 \times 10^{-9} \mathrm{M} \mathrm{E}_{2}$. The internalization and cell localization of AuNPs was assessed by CLSM (Figure 4). The nuclei were stained with DAPI (cyan/blue fluorescence), while AuNP agglomerates (red) were observed by a fluorescent signal emitted by the bare AuNP due to their surface plasmon resonance at $525 \mathrm{~nm} .^{72}$ To ensure that there was no autofluorescence in cells, the emission spectrum was normalized with the ethanol-treated cells (control). These results are reproducible with other techniques such as flow cytometry. ${ }^{73,74}$

Cells that were incubated with the $\mathrm{AuNP} / \mathrm{E}_{2}$ mixture contained greater amounts and larger clusters of AuNPs near to the nuclei compared to those that were only incubated with the nanomaterial, as observed in the digitally zoomed images (magnification), with similar results having been reported by Kodiha et $\mathrm{al}^{75}$. These results suggest that a greater amount of $\mathrm{AuNP}$ was incorporated due to the effect of $\mathrm{E}_{2}$ on the plasma
Control

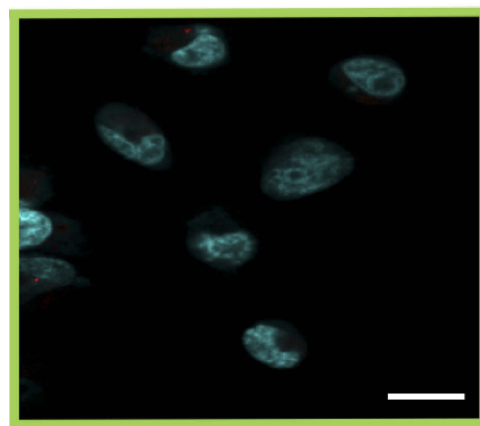

$\mathrm{E}_{2}$

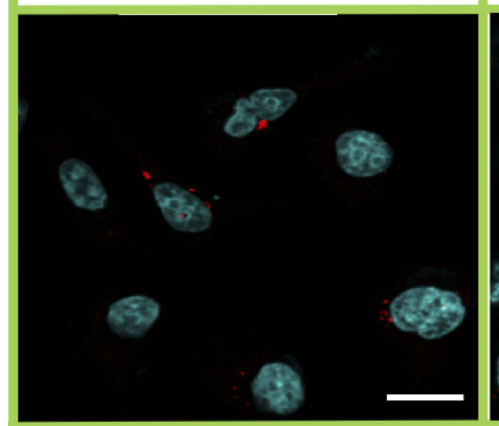

AuNP

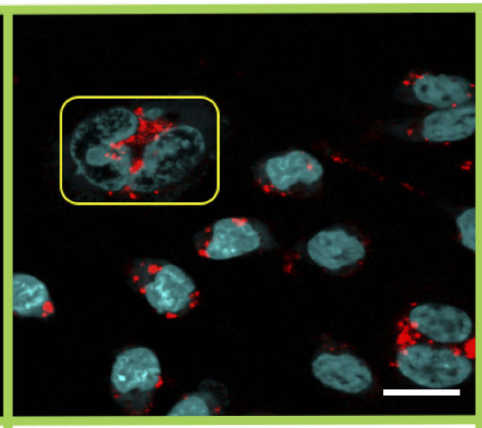

$\mathrm{E}_{2}+\mathrm{AuNP}$

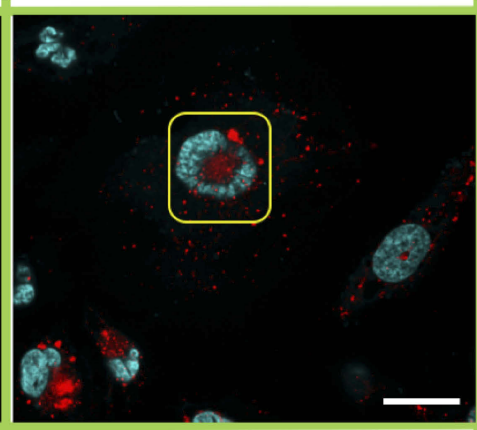

Magnification

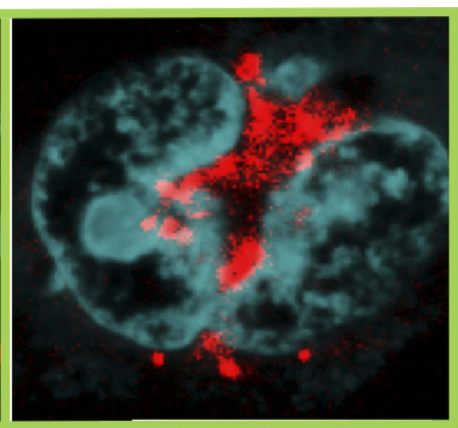

Magnification

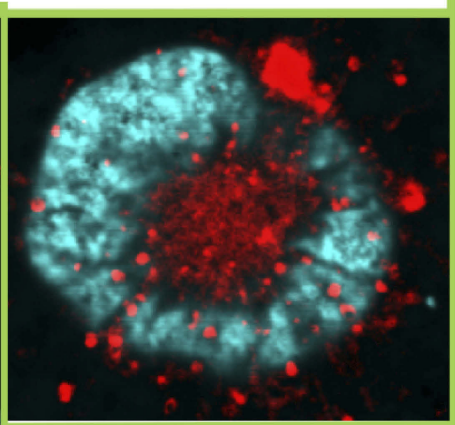

Figure 4 Representative CLSM images of intracellular AuNPs after $12 \mathrm{~h}$ of incubation in MCF-7 cells. AuNP uptake is enhanced by $E_{2}$ and particles are taken closer to the cell nucleus. The fluorescence signal of AuNP (red) was observed around the cell nuclei that were stained with DAPI (cyan). Digitally zoomed images (I0x magnification) are shown in right column to better illustrate the localization of AuNP. Scale bars are $20 \mu \mathrm{m}$.

Abbreviations: AuNP, gold nanoparticle; CLSM, confocal laser scanning microscopy; DAPI, 4',6-diamidino-2-phenylindole. 
membrane, which could be the result of the receptormediated endocytosis. ${ }^{76,77}$

\section{E2-induced vesicle formation enhances AuNP incorporation}

To show that AuNPs are internalized through the endolysosomal route, LT was used to observe lysosome formation. $E_{2}$ has been proposed to induce internalization via dynamin-dependent, caveolae-mediated endocytosis, ${ }^{47,77}$ and this mechanism was shown to be used by AuNPs to enter cell nuclei in as little as $6 \mathrm{hrs}^{78}$

As observed in Figure 5A, $\mathrm{E}_{2}$ induced endolysosome formation compared with vehicle-treated MCF-7 cells. This effect was directly related to AuNP incorporation, since LT-stained lysosomes (red) colocalized with AuNP clusters (cyan), resulting in white-dotted structures around the nucleus (Figure 5B). This effect was partially precluded by the addition of the ER antagonist ICI, demonstrating the participation of $\mathrm{E}_{2}$, which decreased $\mathrm{E}_{2}$-induced vesicle formation. It is worth noting that vesicles were observed in the ICI-treated cells, which occurred because not all lysosomes depend on estrogen activity. $^{79}$

\section{Hyperspectral imaging}

The HSI of biological samples offers significant advantages by scattering and absorbing light from the minor cellular components depending on their structure and molecular composition. ${ }^{56,80}$ Figure 6A shows the hyperspectral images of a representative MCF-7 cell incubated with $\mathrm{E}_{2}$ and AuNP.

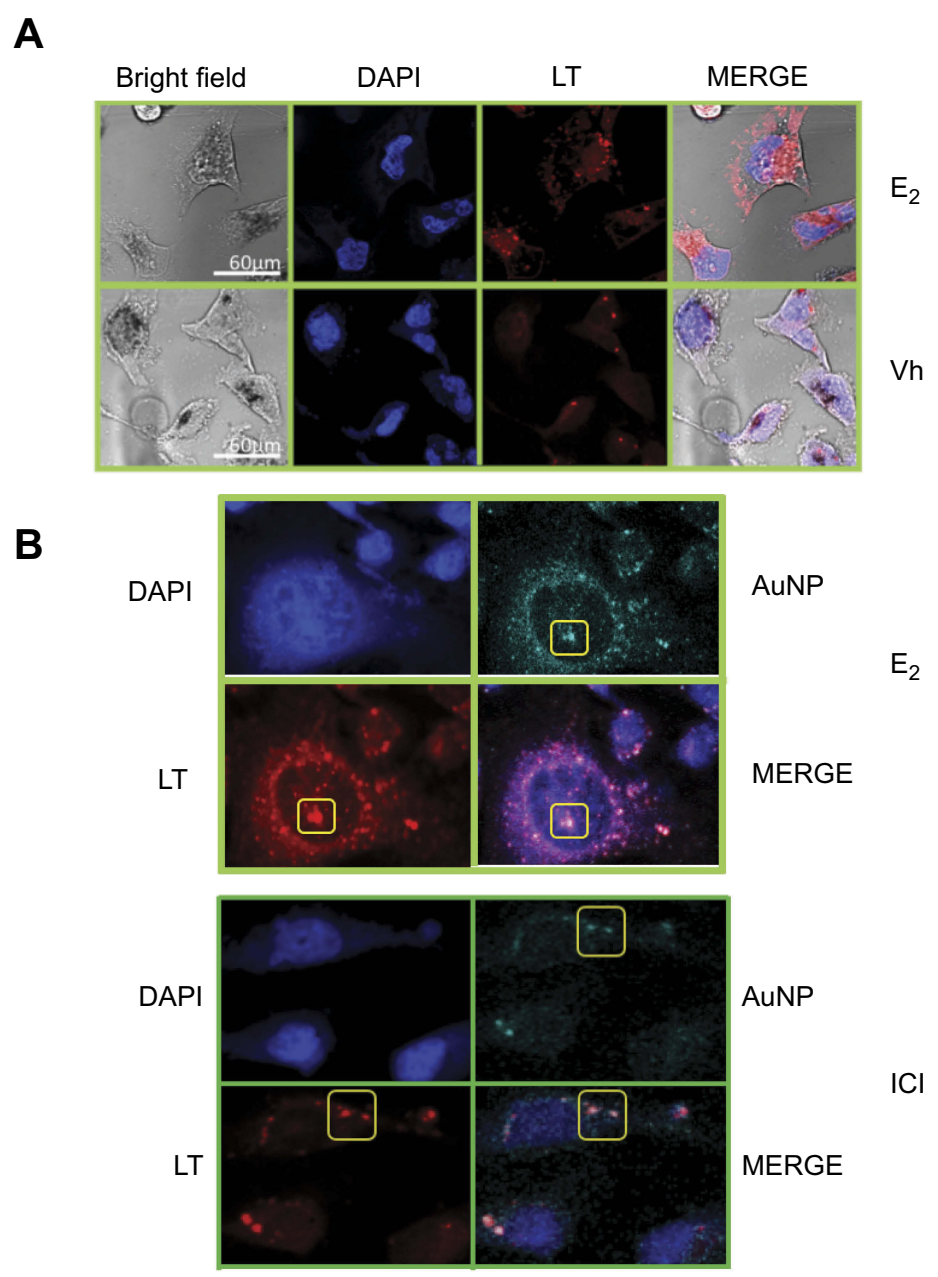

Figure 5 Image shown the effect of $E_{2}$ on cellular AuNP uptake and vesicle formation; representative observations were acquired in CLSM. (A) From left to right it can be seen MCF-7 cells in the bright field, DAPI-stained nuclei (blue), endosomal-lysosomal system stained with LT (red) and highlighted areas of colocalization (squares), where it is shown that $E_{2}$ increases lysosomes formation compared with Vh-treated cells. (B) $E_{2}$ increases AuNP uptake (cyan) by the lysosomes pathway (red), effect that is precluded in the presence of the ER antagonist (ICl). Scale bars are $60 \mu \mathrm{m}$.

Abbreviations: AuNP, gold nanoparticle; CLSM, confocal laser scanning microscopy; DAPI, 4',6-diamidino-2-phenylindole; E2, I7 $\beta$-estradiol; ICI, 7 $\alpha, I 7 \beta-[9-[(4,4,5,5,5-$ Pentafluoropentyl)sulfinyl]nonyl]estra-I,3,5(10)-triene-3, I7-diol; LT, LysoTracker; Vh, vehicle. 
A

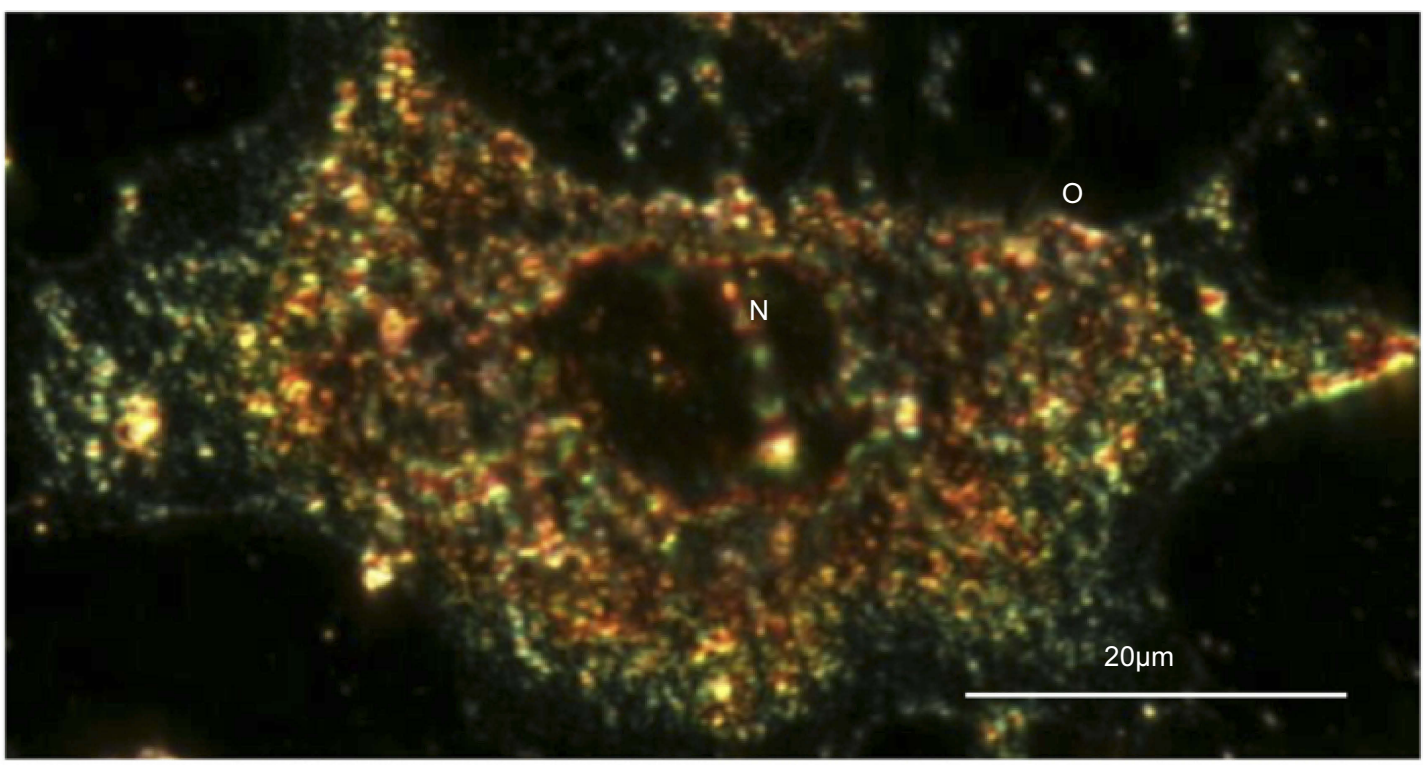

B
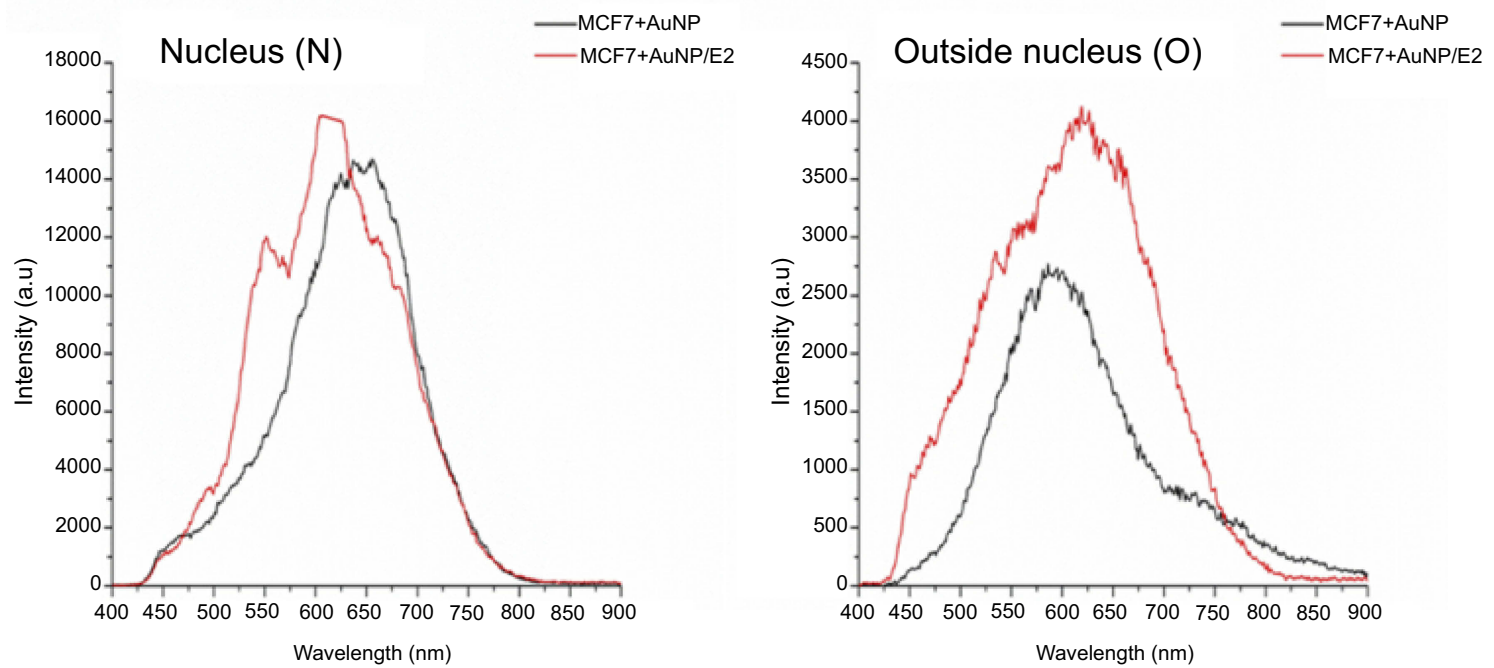

Figure 6 Hyperspectral image (A) and spectra (B) inside MCF7 cell nucleus (N) or the cytoplasmic region, outside nucleus (O). Breast cancer cells were incubated with AuNP, in the presence or absence of $E_{2}$, after 12 hrs. Scattering spectra of the AuNP incubation (black line) is compared with the spectra generated by the co-incubation of $E_{2}$ and AuNP (red line) inside the nucleus (left) or outside (right). The images were acquired using a 50x objective in reflectance mode. The inset letters ( $N$, O) show the regions where hyperspectral image were taken.

Abbreviations: AuNP, gold nanoparticle; $E_{2}, 17 \beta$-estradiol.

Different spectral profiles related to the effects of $E_{2}$ can be observed in Figure 6B, and these variations are directly reflected in the spectral readout of the nucleus or outer cell. The mean spectrum was analyzed for each profile and compared to evaluate the impact of $\mathrm{AuNP}+\mathrm{E}_{2}$. The reference spectra of MCF7+AuNP showed a primary peak at approximately $650 \mathrm{~nm}$. After the addition of $\mathrm{E}_{2}\left(\mathrm{MCF} 7+\mathrm{AuNP} / \mathrm{E}_{2}\right)$, the scattering spectra slightly shifted to $550 \mathrm{~nm}$ as a primary peak and appeared as a second endmember at $500 \mathrm{~nm}$. The nearby intensities of the spectral peaks could be attributed to the large amount of AuNPs near the nucleus. Second, in the collection of the outer cell spectra, the MCF7+AuNP reference spectra showed a peak at $600 \mathrm{~nm}$. When $\mathrm{E}_{2}$ was incorporated $\left(\mathrm{MCF} 7+\mathrm{AuNP}+\mathrm{E}_{2}\right)$, the spectra shifted to $650 \mathrm{~nm}$, and the same shoulder at $500 \mathrm{~nm}$ is present. The $E_{2}$ influence was notably indicated by the presence of a shoulder at $500 \mathrm{~nm}$ in both nuclear $(\mathrm{N})$ and outer/ cytoplasmic (O) spectra. These results clearly confirmed the presence of $A u N P+E_{2}$ in cellular material and allowed the tracking of the cell changes induced by their incorporation.

The HSI results verify the presence of AuNPs in the cell compartments, both in the nucleus and cytoplasmic area, confirming the cellular AuNP uptake and distribution observed by CLSM. 


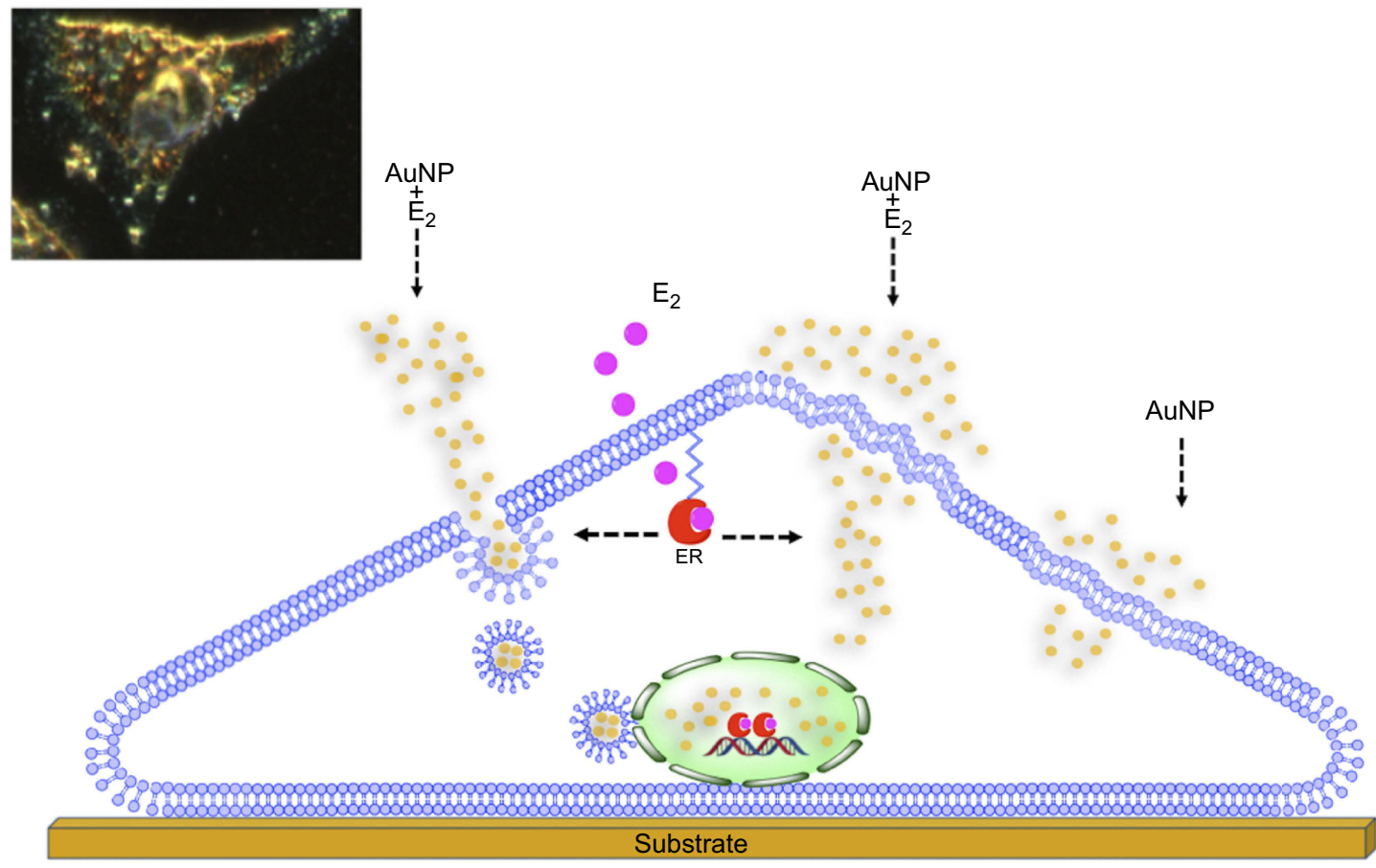

Figure 7 Estradiol $\left(E_{2}\right)$ increases the gold nanoparticles (AuNP) uptake into the breast cancer cell. One mechanism of AuNP cellular internalization is mediated by the formation of vesicle (lysosomes) and the transport to regions nearby the nucleus. Other mechanism can be due to the increase on the cell surface roughness and thereby promoting the AuNP diffusion across the plasma membrane.

\section{Conclusion}

In summary, the AFM results confirmed that AuNP incorporation increased the roughness of the plasma membrane of MCF-7 human breast cancer cells in vitro, and this effect was enhanced by incubating cells with $E_{2}$ at a physiological concentration.

As shown in Figure 7, two different mechanisms are proposed for $E_{2}$-induced AuNP uptake: 1) since $E_{2}$ increases AuNP-induced membrane roughness, their incorporation are observed at shorter times of incubation; and 2) $E_{2}$ treatment increases vesicle (endolysosome) formation in ER-positive MCF-7 cells, allowing more AuNP clusters to become distributed in the cytoplasm and around the nucleus.

The obtained information is of great significance, since it promotes corresponding studies for future clinical use of a possible hormone therapy combined with nanotherapy. This approach could increase the incorporation of these nanomaterials into ER-positive breast cancer cells, have alternative applications in photothermic therapy, and promote the use of AuNPs as fluorescent markers for early cancer diagnosis. These findings may also have implications when AuNPs are used in combination with estrogen or antiestrogen therapy formulations.

\section{Abbreviations list}

AFM, atomic force microscopy; AuNP, gold nanoparticles; CLSM, confocal laser scanning microscopy; DAPI, 4',6-diamidino-2-phenylindole, nuclear fluorescent stain; DMEM, Dulbecco's modified Eagle medium; DPH, diphenylhexatriene; $\mathrm{E}_{2}$, estradiol; $\mathrm{ER}$, estrogen receptor; $\mathrm{E}_{2}, 17 \beta$-estradiol, FBS, fetal bovine serum; HSI, hyperspectral image; ICI, ICI 182,780, ER antagonist; LSPR, localized surface plasmon resonance; LT, LysoTracker; MCF-7 cell line: Michigan Cancer Foundation-7; mER, membrane ER; $\mathrm{RMS}_{[\mathrm{Rq}]}$, rootmean-square, roughness; $\mathrm{Vh}$, vehicle.

\section{Acknowledgments}

The abstract of this paper was presented at the $95^{\text {th }}$ Annual Meeting of the Endocrine Society on June 15, 2013, as a poster presentation, number SAT-309. The poster's abstract was published in the "Meeting Abstracts" of the Endocrine Society at http://press.endocrine.org/doi/ abs/10.1210/endo-meetings.2013.CN.1.SAT-309.

\section{Disclosure}

The authors report no conflicts of interest in this work. 


\section{References}

1. Soto-Perez-de-Celis E, Chavarri-Guerra Y. National and regional breast cancer incidence and mortality trends in Mexico 2001-2011: analysis of a population-based database. Cancer Epidemiol. 2016;41:24-33. doi:10.1016/j.canep.2016.01.007

2. Gmeiner WH, Ghosh S. Nanotechnology for cancer treatment. Nanotechnol Rev. 2015;3(2):111-122. doi:10.1515/ntrev-2013-0013

3. Singh P, Pandit S, Mokkapati VRSS, Garg A, Ravikumar V, Mijakovic I. Gold nanoparticles in diagnostics and therapeutics for human cancer. Int J Mol Sci. 2018;19(7):1979. doi:10.3390/ijms19071979

4. Gao Y, Shen JK, Milane L, Hornicek FJ, Amiji MM, Duan Z. Targeted cancer therapy; nanotechnology approaches for overcoming drug resistance. Curr Med Chem. 2015;22(11):1335-1347.

5. Sharma B, Crist RM, Adiseshaiah PP. Nanotechnology as a delivery tool for precision cancer therapies. Aaps J. 2017;19(6):1632-1642. doi:10.1208/s12248-017-0152-y

6. Huang Q, Wang Y, Chen X, et al. Nanotechnology-based strategies for early cancer diagnosis using circulating tumor cells as a liquid biopsy. Nanotheranostics. 2018;2(1):21-41. doi:10.7150/ntno.22091

7. Beik J, Khademi S, Attaran N, et al. A nanotechnology-based strategy to increase the efficiency of cancer diagnosis and therapy: folate-conjugated gold nanoparticles. Curr Med Chem. 2017;24 (39):4399-4416. doi:10.2174/0929867324666170810154917

8. Jain S, Hirst DG, O'Sullivan JM. Gold nanoparticles as novel agents for cancer therapy. Br J Radiol. 2012;85(1010):101-113. doi:10.1259/ bjr $/ 59448833$

9. Guo J, Rahme K, He Y, Li -L-L, Holmes JD, O’Driscoll CM. Gold nanoparticles enlighten the future of cancer theranostics. Int J Nanomedicine. 2017;12:6131-6152. doi:10.2147/IJN.S140772

10. Kodiha M, Wang YM, Hutter E, Maysinger D, Stochaj U. Off to the organelles - killing cancer cells with targeted gold nanoparticles. Theranostics. 2015;5(4):357-370. doi:10.7150/thno.10657

11. Wu D, Si M, Xue H-Y, Wong HL. Nanomedicine applications in the treatment of breast cancer: current state of the art. Int J Nanomedicine. 2017;12:5879-5892. doi:10.2147/IJN.S123437

12. Candido NM, de Melo MT, Franchi LP, et al. Combining photodynamic therapy and chemotherapy: improving breast cancer treatment with nanotechnology. J Biomed Nanotechnol. 2018;14(5):994-1008. doi:10.1166/jbn.2018.2558

13. Tanaka T, Decuzzi P, Cristofanilli M, et al. Nanotechnology for breast cancer therapy. Biomed Microdevices. 2009;11(1):49-63. doi:10.1007/s10544-008-9209-0

14. Avitabile E, Bedognetti D, Ciofani G, Bianco A, Delogu LG. How can nanotechnology help the fight against breast cancer? Nanoscale. 2018;10(25):11719-11731. doi:10.1039/c8nr02796j

15. Hussain Z, Khan JA, Murtaza S. Nanotechnology: an Emerging Therapeutic Option for Breast Cancer. Crit Rev Eukaryot Gene Expr. 2018;28(2):163- 175. doi:10.1615/CritRevEukaryotGeneExpr. 2018022771

16. Russell LM, Dawidczyk CM, Searson PC. Quantitative evaluation of the enhanced permeability and retention (EPR) effect. Methods Mol Biol Clifton NJ. 2017;1530:247-254. doi:10.1007/978-1-49396646-2_14

17. Bi Y, Hao F, Yan G, Teng L, Lee RJ, Xie J. Actively targeted nanoparticles for drug delivery to tumor. Curr Drug Metab. 2016;17(8):763-782.

18. Lara-Cruz C, Jiménez-Salazar JE, Ramón-Gallegos E, DamianMatsumura P, Batina N. Increasing roughness of the human breast cancer cell membrane through incorporation of gold nanoparticles. Int J Nanomedicine. 2016;11:5149-5161. doi:10.2147/IJN.S108768

19. Glazer ES, Zhu C, Hamir AN, Borne A, Thompson CS, Curley SA. Biodistribution and acute toxicity of naked gold nanoparticles in a rabbit hepatic tumor model. Nanotoxicology. 2011;5(4):459-468. doi:10.3109/17435390.2010.516026
20. Hwang WS, Sim SJ. A strategy for the ultrasensitive detection of cancer biomarkers based on the LSPR response of a single AuNP. J Nanosci Nanotechnol. 2011;11(7):5651-5656.

21. Teixeira RAR, Lataliza AAB, Raposo NRB, Costa LAS, Sant'Ana AC. Insights on the transport of tamoxifen by gold nanoparticles for MCF-7 breast cancer cells based on SERS spectroscopy. Colloids Surf B Biointerfaces. 2018;170:712-717. doi:10.1016/j. colsurfb.2018.07.001

22. Lee J, Chatterjee DK, Lee MH, Krishnan S. Gold nanoparticles in breast cancer treatment: promise and potential pitfalls. Cancer Lett. 2014;347(1):46-53. doi:10.1016/j.canlet.2014.02.006

23. Wang S-H, Lee C-W, Chiou A, Wei P-K. Size-dependent endocytosis of gold nanoparticles studied by three-dimensional mapping of plasmonic scattering images. $J$ Nanobiotechnology. 2010;8:33. doi:10.1186/1477-3155-8-33

24. Coradeghini R, Gioria S, García CP, et al. Size-dependent toxicity and cell interaction mechanisms of gold nanoparticles on mouse fibroblasts. Toxicol Lett. 2013;217(3):205-216. doi:10.1016/j. toxlet.2012.11.022

25. Tan G, Onur MA. Cellular localization and biological effects of 20nm-gold nanoparticles. J Biomed Mater Res A. 2018;106 (6):1708-1721. doi:10.1002/jbm.a.36373

26. Patra S, Mukherjee S, Barui AK, Ganguly A, Sreedhar B, Patra CR. Green synthesis, characterization of gold and silver nanoparticles and their potential application for cancer therapeutics. Mater Sci Eng C Mater Biol Appl. 2015;53:298-309. doi:10.1016/j.msec.2015.04.048

27. Kang JH, Ko YT. Lipid-coated gold nanocomposites for enhanced cancer therapy. Int $J$ Nanomedicine. 2015;10(Spec Iss):33-45. doi:10.2147/IJN.S88307

28. Almeida JPM, Lin AY, Figueroa ER, Foster AE, Drezek RA. In vivo gold nanoparticle delivery of peptide vaccine induces anti-tumor immune response in prophylactic and therapeutic tumor models. Small Weinh Bergstr Ger. 2015;11(12):1453-1459. doi:10.1002/ smll.201402179

29. Ryan JA, Overton KW, Speight ME, et al. Cellular uptake of gold nanoparticles passivated with BSA-SV40 large T antigen conjugates. Anal Chem. 2007;79(23):9150-9159. doi:10.1021/ac0715524

30. Curry D, Cameron A, MacDonald B, et al. Adsorption of doxorubicin on citrate-capped gold nanoparticles: insights into engineering potent chemotherapeutic delivery systems. Nanoscale. 2015;7 (46):19611-19619. doi:10.1039/c5nr05826k

31. Lee C-W, Jang -L-L, Pan H-J, Chen Y-R, Chen -C-C, Lee C-H. Membrane roughness as a sensitive parameter reflecting the status of neuronal cells in response to chemical and nanoparticle treatments. J Nanobiotechnology. 2016;14:1. doi:10.1186/s12951016-0161-5

32. Dobrescu A, Chang M, Kirtani V, Turi GK, Hennawy R, Hindenburg AA. Study of estrogen receptor and progesterone receptor expression in breast ductal carcinoma in situ by immunohistochemical staining in ER/PgR-negative invasive breast cancer. ISRN Oncol. 2011;2011. doi:10.5402/2011/673790

33. Yip C-H RA. Estrogen and progesterone receptors in breast cancer. Future Oncol Lond Engl. 2014;10(14):2293-2301. doi:10.2217/ fon. 14.110

34. Travis RC, Key TJ. Oestrogen exposure and breast cancer risk. Breast Cancer Res BCR. 2003;5(5):239-247. doi:10.1186/bcr628

35. Santen RJ, Yue W, Wang J-P. Estrogen metabolites and breast cancer. Steroids. 2015;99(Pt A):61-66. doi:10.1016/j.steroids.2014.08.003

36. Huang B, Warner M, Gustafsson J-Å. Estrogen receptors in breast carcinogenesis and endocrine therapy. Mol Cell Endocrinol. 2015;418(Pt 3):240-244. doi:10.1016/j.mce.2014.11.015

37. Jiménez-Salazar JE, Posadas-Rodríguez P, Lazzarini-Lechuga RC, et al. Membrane-initiated estradiol signaling of epithelial-mesenchymal transition-associated mechanisms through regulation of tight junctions in human breast cancer cells. Horm Cancer. 2014;5(3):161-173. doi:10.1007/s12672-014-0180-3 
38. Lipovka Y, Konhilas JP. The complex nature of oestrogen signalling in breast cancer: enemy or ally? Biosci Rep. 2016;36(3). doi:10.1042/ BSR20160017

39. Pietras RJ, Szego CM. Estrogen receptors in uterine plasma membrane. J Steroid Biochem. 1979;11(4):1471-1483.

40. Morris JF, Christian HC, Chapman LP, et al. Steroid effects on secretion from subsets of lactotrophs: role of folliculo-stellate cells and annexin 1. Arch Physiol Biochem. 2002;110(1-2):54-61. doi:10.1076/apab.110.1.54.910

41. González M, Reyes R, Damas C, Alonso R, Bello AR. Oestrogen receptor alpha and beta in female rat pituitary cells: an immunochemical study. Gen Comp Endocrinol. 2008;155(3):857-868. doi:10.1016/j.ygcen.2007.10.007

42. May RM, Tabatadze N, Czech MM, Woolley CS. Estradiol regulates large dense core vesicles in the hippocampus of adult female rats. Brain Struct Funct. 2014;219(6):1947-1954. doi:10.1007/s00429013-0614-7

43. Moats RK, Ramirez VD. Electron microscopic visualization of membrane-mediated uptake and translocation of estrogen-BSA: colloidalgold by hep G2 cells. J Endocrinol. 2000;166(3):631-647.

44. Ratajczak J, Wysoczynski M, Hayek F, Janowska-Wieczorek A, Ratajczak MZ. Membrane-derived microvesicles: important and underappreciated mediators of cell-to-cell communication. Leukemia. 2006;20(9):1487-1495. doi:10.1038/sj.leu.2404296

45. Muralidharan-Chari V, Clancy JW, Sedgwick A, D’Souza-Schorey C. Microvesicles: mediators of extracellular communication during cancer progression. J Cell Sci. 2010;123(Pt 10):1603-1611. doi:10.1242/ jes.064386

46. Totta P, Pesiri V, Marino M, Acconcia F. Lysosomal function is involved in $17 \beta$-estradiol-induced estrogen receptor $\alpha$ degradation and cell proliferation. Migliaccio A, ed. PLOS ONE. 2014;9(4): e94880. doi:10.1371/journal.pone.0094880

47. Luoma JI, Boulware MI, Mermelstein PG. Caveolin proteins and estrogen signaling in the brain. Mol Cell Endocrinol. 2008;290(1-2):8-13. doi:10.1016/j.mce.2008.04.005

48. Kim KH, Moriarty K, Bender JR. Vascular cell signaling by membrane estrogen receptors. Steroids. 2008;73(9-10):864-869. doi: 10.1016/j.steroids.2008.01.008.

49. Maselli A, Pierdominici M, Vitale C, Ortona E. Membrane lipid rafts and estrogenic signalling: a functional role in the modulation of cell homeostasis. Apoptosis. 2015;20(5):671-678. doi:10.1007/s10495015-1093-5

50. Mollinedo F, Gajate C. Lipid rafts as major platforms for signaling regulation in cancer. Adv Biol Regul. 2015;57:130-146. doi:10.1016/ j.jbior.2014.10.003

51. Sebastian T, Sreeja S, Thampan RV. Import and export of nuclear proteins: focus on the nucleocytoplasmic movements of two different species of mammalian estrogen receptor. Mol Cell Biochem. 2004;260(1-2):91-102.

52. Peckys DB, de Jonge N. Gold nanoparticle uptake in whole cells in liquid examined by environmental scanning electron microscopy. Microsc Microanal Off J Microsc Soc Am Microbeam Anal Soc Microsc Soc Can. 2014;20(1):189-197. doi:10.1017/ S1431927613013986

53. Ng CT, Tang FMA, Li JJ, Ong C, Yung LLY, Bay BH. Clathrinmediated endocytosis of gold nanoparticles in vitro. Anat Rec Hoboken NJ 2007. 2015;298(2):418-427. doi:10.1002/ar.23051

54. Kumar P, Kale RK, Baquer NZ. Estradiol modulates membrane-linked ATPases, antioxidant enzymes, membrane fluidity, lipid peroxidation, and lipofuscin in aged rat liver. J Aging Res. 2011;2011:580245. doi:10.4061/2011/580245

55. Tsuda K, Kinoshita Y, Kimura K, Nishio I, Masuyama Y. Electron paramagnetic resonance investigation on modulatory effect of 17beta-estradiol on membrane fluidity of erythrocytes in postmenopausal women. Arterioscler Thromb Vasc Biol. 2001;21(8):1306-1312.
56. Mehta N, Shaik S, Devireddy R, Gartia MR. Single-cell analysis using hyperspectral imaging modalities. $J$ Biomech Eng. 2018;140:2. doi:10.1115/1.4038638

57. Moore T, Sorokulova I, Pustovyy O, et al. Microscopic evaluation of vesicles shed by erythrocytes at elevated temperatures. Microsc Res Tech. 2013;76(11):1163-1170. doi:10.1002/jemt.22280

58. Verebes GS, Melchiorre M, Garcia-Leis A, Ferreri C, Marzetti C, Torreggiani A. Hyperspectral enhanced dark field microscopy for imaging blood cells. J Biophotonics. 2013;6(11-12):960-967. doi:10.1002/jbio. 201300067

59. Ş Comşa, Cîmpean AM, Raica M. The story of MCF-7 breast cancer cell line: 40 years of experience in research. Anticancer Res. 2015;35 (6):3147-3154

60. Wang Y, Xu C, Jiang N, et al. Quantitative analysis of the cell-surface roughness and viscoelasticity for breast cancer cells discrimination using atomic force microscopy. Scanning. 2016;38(6):558-563. doi:10.1002/sca.21300

61. Antonio PD, Lasalvia M, Perna G, Capozzi V. Scale-independent roughness value of cell membranes studied by means of AFM technique. Biochim Biophys Acta. 2012;1818(12):3141-3148. doi:10.1016/j.bbamem.2012.08.001

62. Wang J, Wan Z, Liu W, et al. Atomic force microscope study of tumor cell membranes following treatment with anti-cancer drugs. Biosens Bioelectron. 2009;25(4):721-727. doi:10.1016/j. bios.2009.08.011

63. Kim KS, Cho CH, Park EK, Jung M-H, Yoon K-S, Park H-K. AFMdetected apoptotic changes in morphology and biophysical property caused by paclitaxel in Ishikawa and HeLa cells. PloS One. 2012;7 (1):e30066. doi:10.1371/journal.pone.0030066

64. Ukraintsev E, Kromka A, Kozak H, Reme Z, Rezek B. Artifacts in atomic force microscopy of biological samples. In: Frewin $\mathrm{C}$, editor. Atomic Force Microscopy Investigations into Biology - from Cell to Protein. London: InTech; 2012. doi:10.5772/36203

65. Canale C, Torre B, Ricci D, Braga PC. Recognizing and avoiding artifacts in atomic force microscopy imaging. Methods Mol Biol Clifton NJ. 2011;736:31-43. doi:10.1007/978-1-61779-105-5_3

66. Hamouchene H, Arlt VM, Giddings I, Phillips DH. Influence of cell cycle on responses of MCF-7 cells to benzo[a]pyrene. BMC Genomics. 2011;12:333. doi:10.1186/1471-2164-12-333

67. Aillon KL, Xie Y, El-Gendy N, Berkland CJ, Forrest ML. Effects of nanomaterial physicochemical properties on in vivo toxicity. $A d v$ Drug Deliv Rev. 2009;61(6):457-466. doi:10.1016/j.addr.2009. 03.010

68. Perner P, Rapp A, Dressler C, et al. Variations in cell surfaces of estrogen treated breast cancer cells detected by a combined instrument for far-field and near-field microscopy. Anal Cell Pathol J Eur Soc Anal Cell Pathol. 2002;24(2-3):89-100. doi:10.1155/2002/ 132504

69. Kim KH, Moriarty K, Bender JR. Vascular cell signaling by membrane estrogen receptors. Steroids. 2008;73(9-10):864-869. doi:10.1016/j.steroids.2008.01.008

70. Francis LW, Lewis PD, Gonzalez D, et al. Progesterone induces nano-scale molecular modifications on endometrial epithelial cell surfaces. Biol Cell. 2018;101(8):481-493. doi:10.1042/BC20080189

71. Totta P, Pesiri V, Enari M, Marino M, Acconcia F. Clathrin heavy chain interacts with estrogen receptor $\alpha$ and modulates $17 \beta$-estradiol signaling. Mol Endocrinol Baltim Md. 2015;29(5):739-755. doi:10.1210/me.2014-1385

72. Ujihara M, Dang NM, Imae T. Fluorescence quenching of uranine on confeito-like Au nanoparticles. J Nanosci Nanotechnol. 2014;14 (7):4906-4910.

73. Shukla RS, Jain A, Zhao Z, Cheng K. Intracellular trafficking and exocytosis of a multi-component siRNA nanocomplex. Nanomedicine Nanotechnol Biol Med. 2016;12(5):1323-1334. doi:10.1016/j. nano.2016.02.003 
74. Park J, Ha MK, Yang N, Yoon TH. Flow cytometry-based quantification of cellular Au nanoparticles. Anal Chem. 2017;89(4):2449-2456. doi:10.1021/acs.analchem.6b04418

75. Kodiha M, Hutter E, Boridy S, Juhas M, Maysinger D, Stochaj U. Gold nanoparticles induce nuclear damage in breast cancer cells, which is further amplified by hyperthermia. Cell Mol Life Sci. 2014;71(21):4259-4273. doi:10.1007/s00018-0141622-3

76. Tortorella S, Karagiannis TC. Transferrin receptor-mediated endocytosis: a useful target for cancer therapy. J Membr Biol. 2014;247(4):291-307. doi:10.1007/s00232-014-9637-0
77. Marczell I, Balogh P, Nyiro G, et al. Membrane-bound estrogen receptor alpha initiated signaling is dynamin dependent in breast cancer cells. Eur J Med Res. 2018;23(1):31. doi:10.1186/s40001-018-0328-7

78. Unak G, Ozkaya F, Medine EI, et al. Gold nanoparticle probes: design and in vitro applications in cancer cell culture. Colloids Surf B Biointerfaces. 2012;90:217-226. doi:10.1016/j.colsurfb.2011.10.027

79. Morgan AJ, Platt FM, Lloyd-Evans E, Galione A. Molecular mechanisms of endolysosomal Ca2+ signalling in health and disease. Biochem J. 2011;439(3):349-374. doi:10.1042/BJ20110949

80. Lu G, Fei B. Medical hyperspectral imaging: a review. J Biomed Opt. 2014;19(1):10901. doi:10.1117/1.JBO.19.1.010901

\section{Publish your work in this journal}

The International Journal of Nanomedicine is an international, peerreviewed journal focusing on the application of nanotechnology in diagnostics, therapeutics, and drug delivery systems throughout the biomedical field. This journal is indexed on PubMed Central,

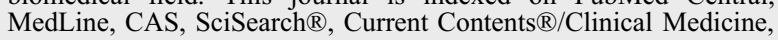

Journal Citation Reports/Science Edition, EMBase, Scopus and the Elsevier Bibliographic databases. The manuscript management system is completely online and includes a very quick and fair peer-review system, which is all easy to use. Visit http://www.dovepress.com/ testimonials.php to read real quotes from published authors. 